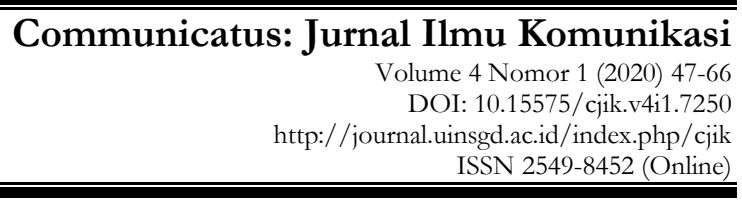

\title{
Fenomena Industri Buzzer di Indonesia: Sebuah Kajian Ekonomi Politik Media
}

\author{
Shiddiq Sugiono ${ }^{1 *}$ \\ Universitas Indonesia Jakarta \\ *email.sugionoshiddiq@gmail.com
}

\begin{abstract}
This study aims to examine the shift in the buzzer concept, look at the various relationships between actors involved in the political buzzer industry, illustrate the abuse of regulations by the authorities and examine the buzzer industry in the concepts of media politics and economic theory. This research uses a descriptive qualitative approach. The research data was collected purposively and prioritized sourced from literature studies and documents examining the buzzer phenomenon in Indonesia. The results show that the buzzer term has shifted to a concept that generally resides in a political context and has negative stereotypes. There are various relations between actors who want to achieve their political goals by using a buzzer. The ruling party is considered to have misused the ITE Law as a tool to trap various sirens from the opposing parties. From the perspective of the political economy, the buzzer industry is often considered to ignore different ethics, one of which is by making one's personal life an industrial commodity. The emergence of political buzzer must be accompanied by public awareness to be vigilant and critical of messages on social media so that it is not provoked by the buzzer industry.
\end{abstract}

Keywords : political burzer, political economy of media, social media

\section{ABSTRAK}

Penelitian ini bertujuan untuk mengkaji pergeseran konsep buzzer, melihat berbagai relasi antar aktor yang terlibat dalam industri buzzer politik, menggambarkan penyalahgunaan regulasi oleh pihak yang berkuasa dan mengkaji industri buzzer dalam konsep-konsep teori ekonomi politik media. Penelitian ini menggunakan pendekatan kualitatif deskriptif. Data penelitian dikumpulkan secara purposive dan diutamakan bersumber dari studi literatur dan dokumen yang mengkaji fenomena buzzer di Indonesia. Hasil penelitian menunjukan bahwa istilah buzzer mengalami pergeseran menjadi konsep yang secara umum berada di dalam konteks politik dan memiliki stereotip negatif. Terdapat berbagai relasi antar aktor yang ingin mencapai tujuan politiknya dengan menggunakan buzzer. Pihak yang berkuasa dinilai telah menyalahgunakan UU ITE sebagai suatu alat untuk menjerat berbagai buzzer dari pihak lawan. Dalam perspektif ekonomi politik, industri buzzer dinilai kerap mengabaikan berbagai etika, salah satunya dengan menjadikan kehidupan pribadi seseorang menjadi suatu komoditas industri. Munculnya buzzer politik harus dibarengi dengan kesadaran masyarakat untuk waspada dan mengkritisi pesan-pesan di media social, sehingga tidak terprovokasi oleh industri buzzer.

Kata kunci : buzzer politik, ekonomi politik media, media sosial 


\section{PENDAHULUAN}

Penulisan artikel ini bertujuan untuk menjelaskan relasi antara pemerintah yang berkuasa, tokoh elit politik serta tokoh publik dalam mempertahankan dan meraih kepentingan politiknya melalui kampanye di media sosial dengan bu₹zer.

Kemajuan teknologi komunikasi Indonesia telah menjadikan media sosial sebagai salah satu media yang memegang peranan penting dalam menyampaikan kampanye politik. Beberapa orang menggunakan momentum kontestasi politik sebagai ajang untuk mencari keuntungan finansial, salah satunya dengan bekerja menjadi bu₹zer di media sosial. Bu₹zer dinilai memiliki peran yang cukup penting dalam membentuk suatu topik pembicaraan di media sosial, sehingga tidak sedikit tokoh atau kandidat politik tertentu memberdayakan mereka untuk memenangkan kontestasi politik tersebut. Adapun melalui sifat interaktivitasnya, media sosial memungkinkan penggunanya untuk ikut bersuara pada sebuah topik percakapan tertentu.

Fenomena munculnya buгzer politik perlu mendapatkan perhatian khusus dalam dunia akademik. Buzzer politik telah menjadi bagian dari pengguna media sosial dan digunakan sebagai propaganda politik di berbagai negara (Bradshaw \& Howard, 2019). Dalam konteks Indonesia Buгzer politik dinilai telah mencederai proses demokrasi, karena konten-kontennya mampu memecah belah masyarakat (Syahputra, 2017). Selain itu, terdapat isu bahwa buzzer pro-pemerintah telah kebal terhadap jeratan hukum (Arigi, 2019). Dibalik kemampuannya dalam mengamplifikasi pesan secara masif, buzzer cenderung menyampaikan kampanye politik negatif (Mustika, 2019). Buzzer memiliki peran penting untuk memfasilitasi elit politik dalam melakukan kampanye (Saraswati, 2018). Berdasarkan beberapa gagasan tersebut maka sudah seharusnya fenomena munculnya industri buzzer tidak hanya dilihat dari perspektif positivistik yang melihat bahwa mereka adalah dampak dari kemajuan teknologi komunikasi, namun perlu ada kajian yang membongkar suatu alasan mengapa mereka terus dibiarkan bertumbuh dan tetap menyuarakan pesan-pesan yang negatif.

Istilah Bu₹zer sendiri berasal dari ranah pemasaran (marketing) yang awalnya berupa istilah buz飞, marketing atau teknik pemasaran barang atau jasa untuk menghasilkan bisnis dengan pergerakan informasi dari mulut ke mulut (Mustika, 2019). Istilah Buzzer sendiri mulai populer ketika berkembangnya teknologi media sosial. Dalam ranah media sosial, buzzer tidak hanya bertugas untuk mengunggah cuitan saja namun menjalankan kampanye kepada follower. Buгzer dianggap memiliki kekuatan untuk mempengaruhi karena kemampuanya untuk menjangkau dan mendistribusikan konten kepada berbagai pengguna media sosial (Saraswati, 2018). Tren buzzer mulai hadir di Indonesia pada tahun 2009 dimana media sosial twitter mulai secara luas diterima dan digunakan oleh masyarakat (Dimedjo, 2019). Bahkan hingga saat ini buzzer sendiri adalah suatu 
industri yang turut bergerak dengan agensi atau biro komunikasi (Mustika, 2019). Tidak hanya di twitter, berbagai media sosial telah menjadi lingkup kerja buzzer. Buzzer ini dinilai sebagai implikasi dari tumbuhnya media sosial dan memiliki peran penting dalam membentuk suatu topik percakapan di media sosial.

Saat ini objek dari promosi buzzer mengalami pergeseran, yang pada awalnya memasarkan produk komersil dari suatu perusahaan menjadi tokoh publik yang mencalonkan diri menjadi pemimpin di lembaga pemerintahan. Buzzer bertugas untuk membangun dukungan rakyat terhadap suatu calon pemimpin yang sedang berkampanye. Kontestasi politik di Indonesia telah menjadikan media sosial sebagai salah satu media yang memegang peranan penting dalam menyampaikan kampanye politik. Dalam penelitian ini, buzzer politik adalah akun media sosial baik yang dikelola individu maupun perusahaan dimana akun tersebut memiliki follower dalam jumlah banyak dan turut melakukan kampanye politik dengan menyebar berbagai berita hoax serta ujaran kebencian (Mustika, 2019; Syahputra, 2017).

Peran buzzer dalam membangun persepsi publik saat kampanye politik telah menjadi sorotan dunia. Bradshaw \& Howard (2019) telah merilis hasil penelitiannya mengenai penggunaan buzzer di berbagai negara. Penggunaan buzzer dalam konteks berpolitik sudah hampir dilakukan pada seluruh belahan dunia. Sebanyak 89\% dari 70 negara yang menjadi subjek penelitiannya menggunakan buzzer untuk menyerang lawan politiknya. Di Indonesia sendiri, buzzer digunakan oleh politisi dan partai politik dalam membangun opini dan dukungan publik terhadap suatu calon pemimpin. Kecenderungan buzzer Indonesia adalah membangun topik menggunakan akun-akun palsu yang dikendalikan baik oleh manusia maupun robot dalam jumlah besar untuk menciptakan konten yang bersifat minsinformasi dan disinformasi. Masifnya pesan yang diproduksi oleh buzzer menyebabkan topik pembicaraannya akan menjadi trending topic di media sosial.

Dalam konteks Indonesia, buzzer telah digunakan oleh tokoh publik yang berkuasa untuk melanggengkan kekuasaannya. Regulasi disusun untuk menjadi senjata pertahanan dari gempuran pencemaran nama baik. Undang-Undang Informasi dan Transaksi Elektronik (UU ITE) dinilai telah menjadi alat pertahanan diri pemerintah dalam melumpuhkan bu₹zer lawan politiknya. Bahkan aparat negara dinilai cukup sering menggunakan pasal UU ITE mengenai pencemaran nama baik. Bila dilihat dari perspektif kritis, kondisi ini tidak dipandang hanya sebagai dampak dari munculnya media sosial saja, namun ada aktor-aktor yang saling berhubungan untuk mempertahankan kepentingannya.

Beberapa penelitian sebelumnya telah meneliti mengenai peran bu₹zer pada kampanye politik dalam berbagai konteks dan teori. Jati (2017) menyatakan bahwa kelas menengah telah menjadi target kampanye politik dari bu₹zer maupun 
influencer karena mereka aktif dalam menyebarkan konten-konten dalam media sosial. Idris (2018) memetakan jaringan sosial yang terbentuk terhadap percakapan dengan tagar \#DukungGermas yang diinisiasi oleh Kementerian Kesehatan Republik Indonesia. Idris (2018) menyampaikan bahwa penggunaan buzzer tidak membangun komunikasi dua arah pada saat terjadi krisis dan cenderung akan menghancurkan reputasi suatu organisasi. Saraswati (2018) dalam kajiannya mengenai media sosial dan industri kampanye politik di Indonesia menyatakan bahwa suatu kampanye politik perlu didukung oleh kekuatan ekonomi untuk menggerakan industri kampanye politik serta telah terjadi komodifikasi pada media sosial sebagai media untuk melakukan kampanye. Felicia (2019) melalui penelitian studi kasus berkesimpulan bahwa buzzer dengan imbalan tertentu memiliki peran untuk memperluas suatu informasi melalui retweet dan penggunaan tagar sehingga dapat dilihat oleh pengguna media sosial dalam bentuk trending topic. Penelitian ini akan menawarkan kebaruan berupa kajian mengenai buzzer politik melalui perspektif teori ekonomi politik komunikasi.

Tulisan ini akan menunjukan bagaimana peran pemerintahan, elit politik serta tokoh publik dalam menggunakan kuasanya untuk menggerakan buzzer melalui teori ekonomi politik media. Kajian ekonomi politik dalam arti sempit berusaha untuk menjelaskan relasi kuasa antara berbagai aktor yang mampu mempengaruhi alur produksi, distribusi hingga konsumsi suatu pesan media. Sedangkan dalam arti yang luas adalah kajian yang mempelajari kontrol dan kelangsungan hidup dalam kehidupan sosial (Mosco, 2009). Pengertian mengenai ekonomi politik secara sederhana adalah hubungan yang melibatkan kekuasaan (politik) dan berbagai sumber ekonomi di masyarakat. Sudut pandang Mosco mengenai penguasa lebih menekankan pada orang-orang yang mengendalikan kehidupan bermasyarakat, adapun dasar kehidupan sosial adalah ekonomi. Sehingga pendekatan ekonomi politik ialan suatu cara pandang untuk membongkar permasalahan yang tampak pada permukaan (Manggaga, 2019).

Implementasi teori ekonomi politik dalam kajian komunikasi akan mengaplikasikan konsep komodifikasi, spasialisasi dan strukturasi (Mosco, 2009). Komodifikasi dalam kajian komunikasi melibatkan transformasi pesan menjadi produk yang menarik sehingga dapat dijual di pasaran (Mosco, 2009). Strukturasi adalah suatu proses dimana struktur sosial saling dijaga oleh agen sosial dan masing-masing bagian dapat bertindak untuk melayani bagian lainnya. Isu mengenai kelas sosial, pergerakan sosial dan hegemoni merupakan bagian dari bahasan strukturasi. Seiring dengan berkembangnya teknologi media, teori ekonomi politik saat ini telah memasuki ranah media online, dalam hal ini spasialisasi adalah suatu upaya untuk mengatasi hambatan ruang dan waktu dengan memanfaatkan teknologi komunikasi sehingga memberikan kemudahan bagi pengguna media sosial untuk mendapatkan konten kampanye politik. 
Penelitian ini menggunakan pendekatan kualitatif deskriptif untuk menjelaskan suatu kasus serta menerapkan paradigma kritis untuk membongkar ketidakberesan sosial yang terjadi dalam kampanye politik menggunakan bu₹zer. Data dikumpulkan melalui berbagai macam sumber dan diutamakan bersumber dari studi literatur dan dokumen. Adapun data penelitian dipilih secara purposive, sehingga data yang dipilih tersebut mampu menunjukan bukti-bukti bahwa terdapat suatu ketidakberesan sosial dalam indusktri buzzer politik. Data yang telah terkumpul akan dianalisis menggunakan teori yang menjadi landasan penelitian ini dan disajikan sesuai dengan konsep-konsep yang relevan.

\section{HASIL DAN PEMBAHASAN}

\section{Pergeseran Peran Buzzer dari Ranah Bisnis Menjadi Politik}

Indonesia termasuk salah satu negara dengan pengguna media sosial tertinggi di dunia. Adapun hal ini terjadi karena pertumbuhan pengguna Internet di Indonesia telah berkembang secara pesat. Media tersebut telah menjadi bagian yang tidak bisa terpisahkan dari kehidupan masyarakat Indonesia. Survei nasional Asosiasi Penyelenggara Jasa Internet Indonesia (APJII) mengenai penetrasi dan profil perilaku pengguna internet di Indonesia turut menyebutkan bahwa rata-rata persentase pertumbuhan pengguna internet di Indonesia adalah sebesar 10,12\% dimana antara tahun 2017-2018 terdapat 27.916 .716 pengguna internet baru. Adapun motif mengoperasikan media sosial menjadi salah satu alasan yang kuat masyarakat Indonesia dalam menggunakan internet. Fakta-fakta tersebut tetap mempertahankan gagasan bahwa di masa depan media sosial semakin menjadi media utama yang digunakan seseorang untuk berkomunikasi.

Pada awalnya, buzzer mulai dikenal sebagai sebagai seorang individu atau akun yang memiliki kemampuan untuk mengamplifikasi pesan dengan menarik perhatian atau membangun percakapan pengguna media sosial dengan motif tertentu. Istilah buzzer sendiri muncul pada tahun 2009 untuk kepentingan promosi suatu perusahaan. Tahun itu merupakan awal dimana media sosial twitter hadir di Indonesia. Adapun pada tahun 2009 terjadi ledakan pengguna media sosial di Indonesia dan alur informasi di media sosial menjadi bergerak sangat cepat (Dimedjo, 2019). Pada periode ini konsep buzzer masih berada dalam konotasi positif sebagai tokoh yang membantu perusahaan dalam strategi pemasaran.

Buгzer politik disinyalir mulai bangkit pada periode Pilkada DKI Jakarta tahun 2012. Saraswati (2018) menjelaskan bahwa pada periode tersebut terdapat dua jenis buzzer. Jenis pertama adalah mereka yang tidak dibayar dan mendistribusikan pesan secara sukarela, kelompok tersebut secara umum mendukung Jokowi. Adapun buzzer yang dibayar dimana mereka disewa untuk mendukung kelompok politik Foke. Pada periode tersebut pula muncul berbagai 
akun twitter seperti@triomacan2000 dan@kurawa. Akun twitter (a)triomacan2000 yang dalam hal ini disewa oleh Foke berfokus dalam menyerang kehidupan pribadi Jokowi. Pada periode ini, buzzer yang awalnya memiliki konotasi positif perlahan-lahan bergeser menjadi negatif karena pesanpesannya yang bersifat menyerang identitas seorang kandidat.

Sejarah mengenai industri buzzer di Indonesia tidak dapat dilepaskan dari kronologi penggunaan buzzer di luar negeri. Pemilihan presiden di Amerika Serikat dalam hal ini dapat menjadi contoh bagi pemberdayaan buzzer untuk melakukan kampanye politik. Ahli Ilmu Politik dari Universitas Airlangga, Airlangga Pribadi, menyebutkan bahwa kemenangan Donald Trump dalam pemilihan presiden Amerika Serikat tahun 2016 turut didukung oleh buzzer politik (Taylor, 2016). Airlangga menyatakan bahwa buzzer politik yang berada pada pihak Trump menyerang lawan politiknya, Hillary Clinton, melalui informasi yang provokatif serta mendorong kebencian, bahkan tidak mempertimbangkan kebenaran dari suatu informasi. Informasi tersebut dinilai lebih cepat bergulir di media sosial karena lebih mudah memancing respons dari pengguna lainnya.

Jauh sebelum periode dimana Trump menggunakan buzzer politik, mobilisasi media sosial yang dilakukan oleh Barack Obama dalam kampanye politik tahun 2008 dinilai sebagai titik balik dimana media sosial menjadi alat untuk memenangkan kontestasi politik. Pada saat itu, Obama mengorganisir penggunaan media sosial sehingga dapat memobilisasi pergerakan masyarakat yang ingin mendukungnya (Syahputra, 2017). Selain itu, Obama turut aktif menggunakan situs online seperti websitemy.barrackobama.com untuk memperluas jangkauan kampanye politiknya. Konsep kampanye politik Obama tersebut dinilai menjadi inspirasi bagi sistem kampanye politik Jokowi-Ahok pada Pilkada DKI Jakarta 2012 karena mereka menggunakan sistem yang serupa dalam mengorganisir media sosial. Pada tahun 2012 tersebut, di Indonesia mulailah tumbuh industri buzzer sebagai alat untuk berperang konten di media sosial.

Twitter menjadi media sosial yang sering digunakan oleh buzzer dalam menyampaikan kampanye seorang tokoh politik. Pada Pilkada DKI Jakarta 2012, twitter digunakan oleh para buzzer untuk menyampaikan ujaran kebencian sehingga menimbulkan istilah perang status atau twitwar (Syahputra, 2017). Twitter menjadi media sosial yang paling aktif digunakan oleh buzzer politik Donald Trump pada pemilihan Presiden Amerika Serikat Tahun 2016 (Taylor, 2016). Pada satu titik, twitter ini mampu membentuk agenda setting dimana topik yang dibicarakan pada twitter menjadi topik yang dibicarakan pada media tradisional (Conway et al., 2015). Namun, pada akhirnya buzzer tidak hanya menggunakan twitter saja, media sosial seperti facebook, instagram, youtube ataupun whatsapp menjadi media untuk mendistribusikan pesan-pesan 
kampanye politik agar jangkauan khalayak menjadi lebih luas (Bradshaw \& Howard, 2019).

Secara umum penggunaan bu₹zer politik menjadi salah satu strategi kampanye politik untuk meningkatkan elektabilitas dan popularitas suatu tokoh atau partai politik. Bradshaw \& Howard (2019) menjelaskan berbagai cara yang digunakan oleh buzzer politik untuk mencapai tujuannya tersebut. Dalam konteks Indonesia, buгzer menggunakan robot dan tenaga manusia untuk mengelola akun palsu. Jenis-jenis pesan yang disampaikan oleh buzzer berupa dukungan dan penyerangan terhadap suatu kandidat serta membuat sebuah polarisasi (memecah masyarakat). Strategi komunikasi yang digunakan adalah penyebaran konten misinformasi dan disinformasi serta amplifikasi konten. Secara praktis, Jati (2017) menjelaskan bahwa lingkup kerja buzzer politik adalah memproduksi kultwit (kuliah twitter) atau mini-story dengan gaya bahasa yang akademis dan teknokrat, mendistribusikan pesan dengan akun anonim, kontenkonten yang bersifat hit and run serta testing the water sehingga wacana yang dilemparkan bersifat sementara dan hanya untuk melihat aksi dan respons dari pengguna media sosial kelas menengah. Pada akhirnya buzzer politik dinilai tidak memberikan edukasi politik jangka panjang kepada pengguna media sosial lainnya bahkan kepada masyarakat Indonesia secara luas.

Setelah Pilkada DKI Jakarta tahun 2012, buzzer politik di Indonesia kembali menjadi sorotan pada saat pemilihan umum 2014, 2019 serta pilkada DKI Jakarta tahun 2017. Pada ketiga periode tersebut buzzer politik masih berkutat dengan isu identitas. Pada tahun 2014, bu₹zer politik cenderung lebih menyoroti kepribadian dari kedua paslon. Sedangkan pada pemilihan umum tahun 2019, buzzer politik dari masing masing kubu menggemakan pesan-pesan yang bertemakan agama. Hal ini dimulai setelah terjadinya gerakan aksi masa 212 pada tahun 2016 (Fernandes, 2019). Berbagai akun twitter muncul dengan mengkampanyekan isu agama. Pada momentum ini pula diindikasikan adanya kelompok-kelompok tertentu yang ingin mendapatkan porsi pemerintahan setelah paslon yang didukungnya terpilih nanti. Adapun strategi kampanye pada Pemilu 2019 berhasil memecah masyarakat menjadi dua kubu/terjadi polarisasi. Fenomena tersebut bisa saja menjadi salah satu penyebab bergesernya konsep buzzer yang memiliki stereotip negatif di mata publik.

Seiring dengan pergeseran konsep buzzer di media sosial, berbagai literatur secara langsung menyatakan bahwa bu₹zer adalah sosok yang berbahaya bagi keberlangsungan demokrasi. Felicia (2019) menjelaskan bahwa peran bu₹zer menjadi berbahaya jika mereka membangun persepsi atau sudut pandang publik terhadap kandidat politik tertentu melalui berita-berita yang bersifat hoax atau hate speech. Cara kerja buzzer seperti itu dinilai mampu menimbulkan perpecahan di masyarakat. Syahputra (2017) menjelaskan bahwa buzzer di Indonesia lebih 
mengedepankan ujaran kebencian, percakapan yang saling mencerca, perdebatan yang penuh amarah bahkan merupakan agen yang menyebarluaskan hoax kepada masyarakat. Hal ini harus menjadi perhatian segala pihak yang terkait karena media sosial akan menjadi media yang paling berpengaruh pada kontestasi politik tahun-tahun selanjutnya dan jika buzeer terus dibiarkan memproduksi konten yang tidak berkualitas maka dapat menghancurkan ideologi berpolitik pada generasi yang akan datang.

\section{Relasi Berbagai Aktor dalam Industri Buzzer Politik}

Bradshaw \& Howard (2019) melalui risetnya mengenai pemberdayaan cybertroops tahun 2019 telah memetakan aktor-aktor yang menggunakan buzzer untuk menyampaikan pesan-pesan disinformasi. Bradshaw \& Howard menyatakan bahwa beberapa politisi dan partai politik di Indonesia turut menggunakan jasa buzzer untuk menyebarkan konten-konten disinformasi. Kerja buzzer politik di Indonesia masuk dalam kelompok negara yang berkapasitas rendah karena memiliki siklus pola kerja yaitu hanya aktif pada saat pemilihan umum sedang berlangsung. Hal ini mempertegas gagasan bahwa tokoh publik dan partai politik di Indonesia kerap menggunakan buzzer untuk kepentingannya kekuasaan semata.

Hubungan relasi kuasa antara elit-elit politik dengan pengelola akun buzzer politik telah disampaikan pada beberapa penelitian sebelumya. Saraswati (2018) dalam kajiannya menjabarkan bahwa buzzer politik@triomacan2000 yang aktif pada pemilihan walikota jakarta tahun 2012 tidak lepas dari permainan relasi kuasa antara elit-elit politik. Akun media sosial tersebut dikelola oleh Raden Nuh dan Abdul Rasyid. Raden adalah komisaris dari BUMN PT. Asuransi Berdikari sedangkan Abdul Rasyid merupakan staf ahli Menteri Koordinator Perekonomian, Hatta Radjasa, yang merupakan petinggi di Partai Amanat Nasional (PAN) dan mertua dari anak Presiden Susilo Bambang Yudhoyono. Kedua pengelola akun @ triomacan2000 dilaporkan karena kasus dimana mereka akan menyebarkan konten fitnah terhadap jokowi dan ahok jika tidak menggunakan layanannya.

Buzzer yang menyampaikan kampanye politik tidak hanya merupakan akun-akun yang bersifat anonim namun kalangan selebriti turut menjadi bagian dari kelompok buzzer. Dalam konteks kampanye politik, orang-orang biasa hingga selebriti yang memiliki followers dalam jumlah banyak di media sosial diketahui telah menjadi buzzer (Saraswati, 2018). Berdasarkan wawancara antara Lipson (2018) dengan salah satu politisi partai politik Indonesia, seseorang akan membayar akun yang telah menjadi selebriti di media sosial untuk mendukung ataupun menyerang lawan politik. Berdasarkan beberapa pernyataan tersebut maka pada akhirnya kampanye politik di Indonesia hanya berputar pada siapa yang mampu membayar lebih namun tidak berfokus pada gagasan politik yang 
bersifat mencerdaskan cara berpikir masyarakat.

Sesuai dengan apa yang dinyatakan oleh Saraswati (2018) bahwa orangorang biasa pun dapat menjadi bu₹zer di media sosial. Pada Pilkada DKI Jakarta 2012, tim Joko Widodo (Jokowi) dan Basuki Tjahaja Purnama (Ahok) membentuk Jokowi Ahok Social Media Volunteers (JASMEV) pada tanggal 12 Agustus 2012 (Syahputra, 2017). Pada saat itu 10 relawan media sosial membentuk jaringan informasi yang masif, luas dan bersifat real time. Meskipun JASMEV tersebut digerakan oleh relawan, namun kelompok tersebut tetap dipimpin oleh kalangan elit. Pada saat itu, Kartika Djoemadi ditunjuk sebagai koordinator JASMEV. Bahkan pada Pemilu 2014, Kartika ditunjuk kembali oleh Joko Widodo untuk menjadi koordinator Jokowi Advanced Social Media Volunteers (JASMEV) yang pada periode ini Kartika mengawal lebih dari 30.000 relawan. Setelah Jokowi menang dalam pemilu 2014, terdapat isu bahwa beberapa relawan Jokowi mendapatkan kursi komisaris di BUMN termasuk Kartika Djoemadi (Suryowati, 2015). Jika isu tersebut benar adanya maka JASMEV merupakan kumpulan pekerja yang seolah-olah menjadi relawan karena dalam hal ini pergerakan mereka diarahkan oleh seorang koordinator yang memiliki misi tertentu.

Pada Pemilihan Kepala Daerah DKI Jakarta tahun 2017 media sosial dipenuhi wacana mengenai isu SARA selama masa kampanye (Triantoro, 2019). Hal tersebut disinyalir karena adanya intervensi Partai Keadilan Sosial (PKS) yang mendukung salah satu paslon. Triantoro (2019) turut menyebutkan bahwa PKS dinilai memiliki gerakan islamis yang seperti Majelis Mujahidin Indonesia (MMI), Hizbut Tahrir Indonesia (HTI) dan Front Pembela Islam (FPI) yang memiliki cita-cita menegakkan Indonesia sebagai negara dengan syariat Islam. Dalam periode tersebut pula, pemakaian media sosial di Indonesia naik secara signifikan yaitu sebanyak 176 juta akun (Noviandari, 2015). Yovita (2017) menjelaskan bahwa terdapat sekitar 300 akun yang diblokir oleh kominfo karena dinilai mempunyai motif politik untuk menyebarkan hoax dan isu SARA. Kalangan selebriti turut meramaikan jagat media sosial dengan isu SARA, dalam hal ini mereka dapat dikatakan sebagai buzzer karena jumlah follower mereka yang tidak sedikit. Fenomena ini menunjukan bahwa bu₹zer politik turut memiliki relasi dengan tokoh publik ataupun ormas dimana pesan-pesan yang mereka produksi bermuatan isu-isu untuk menjatuhkan lawan politiknya.

\section{UU ITE Sebagai Alat Pemerintah dalam Mempertahankan Kekuasaan}

UU ITE penting untuk dibahas karena lingkungan kerja bu₹zer politik berada pada dunia maya yang dimana informasi sangat cepat berputar dan silih berganti, terlebih konten-konten buzzer cenderung mengarah pada ujaran kebencian, misinformasi ataupun disinformasi (Mustika, 2019). Mantan Menteri 
Komunikasi dan Informatika Rudiantara menyebutkan di berbagai media pemberitaan bahwa pada dasarnya kehadiran buzzer tidak dipermasalahkan oleh UU ITE. Namun, mantan Menkominfo tersebut menyatakan bahwa yang menjadi fokus UU ITE adalah konten-konten buzzer dan setiap buzzer akan diadili jika mereka terbukti memproduksi dan mendistribusikan konten-konten yang negatif. Jika memang UU ITE ini diimplemenetasikan dengan baik maka seharusnya sudah banyak orang-orang yang terjerat pasal terkait, namun pada kenyataannya tidak demikian.

UU ITE lahir dari sektor pemerintah dan akademik (Atmaja, 2014) dimana pada tahun 1999 Universitas Padjajaran, Institut Teknologi Bandung dan Kementerian Komunikasi dan Informatika menyusun Naskah Akademik Rancangan Undang Undang Pemanfaatan Teknologi Informasi (RUU PTI). Pada tahun 2000, Universitas Indonesia dan Departemen Perindustrian dan Perdagangan RI menyusun Naskah Akademik Rancangan Undang-Undang Informasi Elektronik dan Transaksi Elektronik (RUU IETE). Pada tahun 2003, kedua RUU tersebut diselaraskan menjadi Rancangan Undang-Undang Informasi dan Transaksi Elektronik (RUU ITE). Pada akhirnya, RUU ITE ditindaklanjuti pada tahun 2005 melalui Kementerian Kominfo dan diselesaikan pada tahun 2008. Kebaruan materi dari UU ITE ini antara lain diakuinya informasi dan/atau dokumen elektronik sebagai bukti hukum yang sah, diakuinya tanda tangan elektronik, Hak kekayaan intelektual di dunia maya dan lain sebagainya.

UU Nomor 11 Tahun 2008 atau yang dikenal sebagai UU ITE sendiri adalah suatu simbol bergesernya orientasi, model serta sistem informasi di Indonesia, selain itu menandai kewenangan negara untuk membatasi informasi, termasuk informasi yang berada di internet (Atmaja, 2014). UU ITE dinilai sebagai semangat Indonesia untuk menegakkan kedaulatannya di dunia maya. Atmaja (2014) turut menyampaikan bahwa dibalik hukum negara ada berbagai kekuatan yang secara diam diam bekerja di masyarakat, dalam hal ini hukum hanya menempati posisi yang bergantung pada aktor yang mampu memainkan kekuatan tersebut. Atmaja (2014) memberikan kritik bahwa UU ITE tidak sejalan dengan perkembangan hukum internasional. Di beberapa negara kabar bohong, penghinaan, pencemaran nama baik masuk dalam hukum perdata bahkan dihapuskan karena dinilai sulit untuk dibuktikan dan bersifat subjektif.

UU ITE dinilai memiliki pasal karet sehingga digunakan oleh elit pemerintahan untuk melawan rakyatnya sendiri (Gerintya \& Garnesia, 2019). Namun, sangat disayangkan UU ITE seperti tidak dipermasalahkan oleh pemerintahan dan isu mengenai revisi UU ITE hampir tidak pernah muncul di berbagai media. Direktur Eksekutif Institute For Criminal Justice Reform (ICJR) Anggara Suwahju menyatakan bahwa saat ini UU ITE mengalami tumpang tindih dengan KUHP khususnya pada tindak pidana penghinaan (Erdianto, 
2019). UU ITE dalam hal ini dinilai sebagai sebuah perpanjangan KUHP mengenai tindak pidana penghinaan karena pada KUHP tidak termuat pasal penghinaan yang tertulis pada media online seperti media sosial. Anonimitas di media sosial menjadi salah satu penghalang besar untuk mengetahui siapa sebenarnya pengelola suatu akun. Berbagai kelemahan tersebut seolah-olah tetap dijaga oleh pihak pemerintah sehingga semakin kuat dugaan bahwa UU ITE sebagai senjata pemerintah dari serangan konten media sosial.

Dalam konteks Pemilihan Umum tahun 2019, muncul beberapa isu dimana UU ITE telah dinilai sebagai senjata pemerintah untuk menjaga nama baik mereka di tengah serangan bužer yang menjadi lawan politiknya. Berdasarkan artikel berita dari Tirto.id (Prabowo, 2019), pihak pertahana diduga telah pilih kasih dalam mengimplementasikan UU ITE. Buzzer lawan politik pertahana dinilai lebih sering dan sangat mudah terjerat pelanggaran pada pasal UU ITE dibandingkan buzzer yang berada di posisi pertahana. Bahkan muncul dugaan bahwa pihak kepolisian turut menjadi tameng bagi buzzer politik pertahana terhadap jeratan UU ITE. Pada akhirnya dugaan tersebut harus dibuktikan kebenarannya karena jika memang benar terjadi maka pemerintah sendirilah yang telah merusak proses demokrasi

Pada analisis yang dilakukan oleh website pinterpolitik.com (2019), dijelaskan bahwa terdapat ketidakadilan terhadap pengimplementasian UU ITE. Seorang jurnalis beraliran kritis Dandhy Dwi Laksono dijerat dengan UU ITE karena cuitannya di twitter dianggap merupakan ujaran kebencian berdasarkan SARA. Dandhy juga dikenal sebagai salah satu orang yang ikut memproduksi film Sexy Killers dimana film tersebut membongkar ketidakberesan yang terjadi pada industri batu bara di Indonesia melalui perspektif ekonomi politik. Tulisan artikel pinterpolitik.com tersebut pula membandingkan kasus tersebut dengan buzzer yang pro-pemerintah yang sama sekali tidak terjerat UU ITE meskipun ada indikasi menyebarkan hoax saat terjadi kerusuhan RUU KPK di DKI Jakarta. Adapun diluar konteks buzzer, kasus mengenai tewasnya mahasiswa di Kendari dalam unjuk rasa RUU KPK tidak diusut secepat Dandhy. Fenomena tersebut dinilai dapat menurunkan tingkat kepercayaan masyarakat terhadap pemerintah dalam menegakkan hukum di Indonesia.

Dugaan mengenai penggunaan UU ITE sebagai senjata pemerintah didukung oleh beberapa fakta yang menjelaskan bahwa pelanggaran UU ITE lebih banyak berada pada sektor pencemaran nama baik seseorang. Pada awalnya UU ITE No.11 Tahun 2008 dimaksud untuk menjamin adanya kepastian hukum mengenai berbagai informasi dan transaksi yang dilakukan secara elektronik tetapi dalam implementasinya, regulasi tersebut lebih digunakan untuk menjerat pihak-pihak terkait dengan penghinaan atau pencemaran nama baik. Data dari Southeast Asia Freedom of Expression Network (SAFENet) turut menunjukan bahwa 
pelaporan dengan menggunakan UU ITE memiliki siklus dimana pada tahun dilaksanakannya pemilihan umum terdapat peningkatan yang signifikan dibandingkan dengan tahun yang lainnya (Gerintya, 2018). Adapun hingga Agustus 2018, 49,72\% pasal yang digunakan sebagai dasar pelaporan adalah pasal 27 ayat (3) yang merujuk pada pencemaran nama baik . berdasarkan data yang telah diolah oleh tirto.id, hingga tahun 2018 pelapor kasus UU ITE terbanyak adalah aparat negara yaitu sebesar 35,92\%. Melihat kondisi tersebut, maka semakin kuat dugaan bahwa memang pada akhirnya UU ITE menjadi senjata bagi pemerintah untuk melanggengkan kekuasaannya.

Meskipun dalam pengimplementasiannya memunculkan berbagai kontroversi, permohonan uji materi terhadap pasal mengenai pencemaran nama baik di UU ITE (Pasal 27 Ayat (3)) yang diajukan pada tanggal 28 Desember 2009 dan 29 Januari 2009 ditolak oleh Mahkamah Konstitusi (Atmaja, 2014). Adapun kedua uji materi tersebut dilayangkan oleh pihak-pihak jurnalis karena dalam hal ini jurnalis merasa sangat dirugikan jika mereka menulis artikel yang bersifat kritis. Menurut MK, pasal tersebut bersifat konstitusional dan tidak bertentangan dengan berbagai nilai demokrasi, HAM, dan prinsip negara hukum. Atmaja (2014) turut berkesimpulan bahwa pasal mengenai pencemaran nama baik di UU ITE rentan disalahgunakan oleh penguasa untuk menyerang pegiat HAM. Fenomena tersebut semakin memperlihatkan bahwa terdapat pertarungan kepentingan kaum elit yang dititipkan pada UU ITE dengan rakyatnya.

\section{Industri Buzzer Politik dalam Perspektif Ekonomi Politik Media}

Riuhnya panggung politik di Indonesia di media sosial menjadi sebuah tambang emas bagi para pelaku industri buzzer. Bradshaw \& Howard (2019) menjelaskan bahwa buzzer di Indonesia digaji mulai dari 1 hingga 50 juta Rupiah. Menurut laporan koresponden ABC Australia, mengatakan bahwa partai politik berani membayar buzzer sebesar US\$ 500 untuk setiap konten yang diunggah. Sebuah Partai Politik memahami dan menyadari betul perlunya memberi perhatian yang cukup untuk membangun suatu citra yang menguntungkan, partai politik membutuhkan terciptanya citra positif partai sebagai asset untuk meraih simpati (Muchtar, 2016). Dalam laporan itu pula, komentator politik Indonesia, Denny Siregar pernah ditawarkan menjadi seorang buzzer partai politik dengan bayaran US\$ 1000 per bulan namun Denny menolak penawaran tersebut. Selain itu ada pula buzzer yang menawarkan suatu paket dimana mereka akan mencari berbagai keburukan dari lawan politik dari pengguna jasa dengan harga 200 juta perbulan. Beberapa fakta tersebut menegaskan bahwa pesta demokrasi di Indonesia turut menumbuhkan industri-industri yang sejatinya menghancurkan mentalitas bangsa. Meskipun pada akhirnya buzzer politik merupakan implikasi dari sistem demokrasi (Syahputra, 2017), namun upaya untuk memperbaiki paradigma cara kerja buzzer harus terus dilakukan oleh semua pihak. Pelaku industri buzzer dapat 
dikatakan sebagai orang-orang yang menganut paham kapitalis karena mereka menggunakan momentum pemilihan umum untuk mengekspansi bisnisnya

Berdasarkan penjelasan pada bagian-bagian sebelumnya, terdapat indikasi bahwa buzzer politik menjadi suatu industri yang memiliki relasi dengan berbagai aktor dalam meraih ataupun mempertahankan kepentingan politik. Selain itu, terdapat pula motif ekonomi dibalik kerja buzzer dibalik relasi dengan aktor-aktor tersebut. Fenomena ini menunjukan bahwa teori ekonomi politik dinilai mampu untuk menjelaskan fenomena industri buzzer politik. Adapun fenomena industri buzzer di Indonesia akan dibedah menggunakan konsep spasialisasi, strukturasi dan komodifikasi.

Dalam ranah media online, spasialisasi menjelaskan tentang upaya untuk menghilangkan batasan ruang dan waktu melalui teknologi komunikasi. Buzzer politik tidak hanya bekerja pada media sosial seperti twitter saja namun Instant messaging seperti whatsapp menjadi salah satu media yang menjadi sasaran mereka (Bradshaw \& Howard, 2019). Penggunaan whatsapp dalam hal ini akan memperluas jangkauan penerima pesan kampanye politik. Di negara selain Indonesia bahkan sangat mungkin industri buzzer mengembangkan bisnis peretasan akun orang-orang penting untuk menyampaikan kampanye politik (Bradshaw \& Howard, 2019).

Website menjadi salah satu media yang digunakan oleh buzzer untuk memperluas jangkauan penerima. Pada konteks Pemilu 2019, Dewan Pers memetakan 43.000 situs online yang mengklaim sebagai portal berita, namun dari jumlah tersebut hanya 300 situs saja yang terverifikasi (Murwani \& Elmada, 2019). Situs portal berita yang tidak terverifikasi tersebut sebagian besar diproduksi oleh buzzer politik (Murwani \& Elmada, 2019). Situs online sebagai portal berita merupakan salah satu media yang dapat digunakan untuk membuka lowongan bagi pengiklan. Fakta tersebut membawa kita pada suatu gagasan bahwa pada akhirnya pelaku industri bu₹zer memainkan berbagai lini bisnis selain bisnis utamanya dalam menyampaikan kampanye politik.

Dalam fenomena bu₹zer politik, struktur sosial saling ditegakkan oleh agenagen yang terlibat didalamnya seperti pemerintah, pelaku industri buzzer, tokoh publik dari partai politik atau ormas bahkan publik secara umum. Agen-agen tersebut saling melayani satu sama lain untuk mencapai suatu tujuan tertentu. Berdasarkan bahasan pada bagian sebelumnya, pemerintah membutuhkan pelaku industri bu₹zer untuk menjaga nama baiknya dengan cara membalas serangan buzzer yang mencoba untuk merusak citranya. Adapun buzzer pemerintah mendapat perlindungan khusus sehingga kekuatan mereka di media sosial tidak akan berkurang. Fenomena JASMEV pada pilkada DKI tahun 2012 menggambarkan bahwa kandidat politik dan publik secara umum saling terhubung sehingga muncullah buzzer relawan yang tidak berbayar. Agensi 
Shiddiq Sugiono

komunikasi yang masuk dalam kelompok industri turut memiliki peran dalam menentukan tarif serta memperbanyak akun palsu yang akan digunakan oleh para buzzer (Mustika, 2019).

Strukturasi pada ekonomi politik media turut berkaitan dengan pergerakan sosial yang ada di masyarakat. Dalam konteks media online, pergerakan masyarakat dapat dinilai dengan adanya dukungan atau partisipasi terhadap konten-konten yang ada di media sosial. Buzzer politik kerap memproduksi pesan-pesan kampanye politik dengan nada yang provokatif, sehingga sangat mungkin pengguna media sosial lainnya turut memberikan komentar atau bahkan membagikannya (share) kepada pengguna lainnya. Bahkan seseorang yang memiliki ideologi yang sama dengan akun buzzer tertentu akan membantunya dengan membagikannya secara rutin. Namun pergerakan sosial dalam memutus pesan-pesan yang diproduksi dapat dinilai susah karena buzzer kerap bekerja dengan menggunakan akun-akun palsu yang jumlahnya banyak.

Proses strukturasi menimbulkan sebuah tindakan dan perubahan sosial yang pada dipengaruhi oleh struktur sosial seperti gender, kelas, ataupun ras. Pada periode Pilkada DKI Jakarta tahun 2017, buzzer politik kerap memproduksi konten-konten yang bermuatan isu agama. Hal ini dinilai telah menimbulkan politik sesama di masyarakat dimana orang-orang akan memilih paslon tertentu atas kesamaan kepercayaan (Lestari, 2019). Bahkan isu agama dinilai telah menjadi konsumsi kelompok kelas menengah yang dalam hal ini mereka mulai mentransformasikan identitasnya melalui perilaku konsumsi produk-produk islam termasuk preferensi dukungan politik (Triantoro, 2019).

Pesan-pesan yang diproduksi oleh buzzer di media sosial seolah-olah menimbulkan hegemoni bahwa pertarungan politik yang benar adalah pertarungan yang mereka lakukan. Sebagian besar pengguna media sosial pada akhirnya menganggap hal ini lumrah dan melihat cara pandang dunia politik adalah seperti yang digambarkan oleh para bu₹zer. Seperti yang telah dipaparkan oleh Bradshaw \& Howard (2019), buzzer telah menjadi bagian dari sistem propaganda politik suatu negara. Bradshaw \& Howard menyebutkan bahwa tiap tahun terjadi peningkatan jumlah negara yang menggunakan media sosial sebagai alat untuk melancarkan propaganda politik, adapun pada tahun 2017 terdapat 28 negara sedangkan ditahun 2019 terdapat 70 negara. Hal tersebut semakin menguatkan bahwa telah terjadi hegemoni dimana cara berpolitik saat ini adalah saling menjatuhkan lawannya di media sosial. Sistem berpolitik seperti ini pun turut dilanggengkan oleh pemerintah Indonesia.

Berbagai hal tersebut membawa pada suatu gagasan pada akhirnya kemajuan teknologi tidak hanya membawa hal-hal yang positif. Namun di tangan orang yang salah, media sosial berubah menjadi alat untuk mempengaruhi cara berfikir masyarakat dengan cara yang dinilai negatif. Bahkan media sosial dapat menjadi saluran untuk menyampaikan ideologi dari pihak-pihak yang berkuasa. 
Dalam kondisi seperti ini, dibutuhkan peran agency untuk merubah paradigma buzzer sebagai industri yang merusak sistem demokrasi suatu negara. Agency dalam hal ini adalah agen-agen yang dapat melawan struktur yang berupa kontrol (Ashaf, 2006). Agency secara umum dilihat dalam konteks mikro sebagai seorang individu, namun konsep tersebut dapat pula merujuk pada suatu tindakan kolektif (makro) (Nursatyo, 2012). Dalam hal ini, siapapun bisa menjadi agency baik itu individu, kelompok masyarakat, bahkan pemerintah.

Peran buzzer dalam aktivitas kampanye politik tidak bisa lepas dari terjadinya komodifikasi konten kampanye politik. Segala hal mampu diubah sebagai komoditas untuk memperkaya pemiliki media. Dalam ranah komunikasi, komoditas tersebut ditransformasi menjadi sebuah konten yang memiliki tujuan tersembunyi disamping tujuan utamanya. Pesan yang diproduksi oleh buzzer cenderung tidak memiliki substansi yang kuat dan terkesan menjatuhkan lawan politiknya melalui ejekan yang murahan. Pesan-pesan yang diproduksi oleh buzzer tidak hanya bertujuan untuk berkampanye, lebih dari itu mereka memiliki tujuan untuk menyerang lawan politiknya.

Dalam konteks pemilihan umum 2014, Jati (2017) menyampaikan bahwa sosok dari seorang Jokowi yang bersih, bersahaja dan populis telah dikomodifikasi menjadi pesan kampanye politik oleh para buzzer. Kepribadian Jokowi telah menjadi komoditas bagi para buzzer untuk memproduksi pesanpesan di media sosial. Namun tidak hanya kepribadian yang baik saja, segala keburukan Jokowi, yang mungkin saja merupakan hoax, turut dijadikan konten bagi lawan politiknya untuk menyerang identitas. Kepribadian tokoh politik dalam hal ini telah menjadi komoditas untuk mendapatkan keuntungan finansial. Hal yang sama terjadi pula pada Pilkada DKI Jakarta tahun 2017 yang merubah isu SARA sebagai komoditas, sehingga dapat ditransformasi sebagai sebuah konten untuk menyerang salah satu paslon.

Munculnya konten-konten yang tidak substansial dapat dipetakan dalam beberapa motif. Pertama, buzzer politik harus memproduksi pesan dalam jumlah banyak dalam waktu yang singkat, terlebih mereka harus mencapai trending topic, sehingga pembuatan konten yang memiliki substansi politik sangat tidak mungkin dilakukan. Kedua, penggunaan robot (bot) sebagai alat untuk mengamplifikasi pesan ataupun tagar dalam untuk mencapai trending topic. Ketiga, pesan yang bersifat menyerang merupakan konten-konten yang disukai oleh sebagian besar pengguna media sosial sehingga pesan tersebut mudah teramplifikasi di media sosial. Berdasarkan perspektif ekonomi politik, hal ini lumrah terjadi karena pola pikir industri adalah menggunakan sumber daya yang terbatas untuk mendapatkan hasil yang maksimal.

Industri Buzzer politik tidak lepas dari terjadinya komodifikasi terhadap pengguna media sosial yang dalam hal ini merupakan kelompok khalayak. 
Komodifikasi khalayak berhubungan dengan rating yang dihasilkan dari konten media dimana rating tersebut ditawarkan kepada para pengiklan dengan khalayak sebagai tolak ukur. Khalayak dinilai sebagai komoditas untuk meningkatkan keuntungan finansial dari perusahaan buzzer. Hal ini turut menjadi pertimbangan bagi calon pengguna jasa buzzer agar kampanye mereka sesuai dengan target pasar.

Pengguna media sosial dalam hal ini telah diubah menjadi suatu komoditas yang dijual oleh buzzer. Banyaknya follower yang dimiliki oleh buzzer ataupun popularitas dari suatu tokoh akan menentukan tingginya tarif yang ditawarkan kepada calon pengguna. Judul-judul berita yang bersifat click bait menjadi umpan bagi pengguna media sosial untuk mengunjungi situs portal berita yang telah dibanjiri oleh para pengiklan. Tanpa disadari, khalayak telah menjadi alat untuk meningkatkan keuntungan finansial dari pelaku industri buzzer.

Pekerja pada industri buzzer kerap menciptakan berbagai konten kampanye yang bersifat provokatif. Hal tersebut dimaksudkan agar pengguna media sosial turut menjadi pekerja buzzer dimana mereka membagikan konten-konten buzzer pada akun media sosial masing-masing. Terlebih jika pengguna media sosial memiliki ideologi yang sama dengan konten-konten yang disampaikan oleh para buzzer, proses sharing akan berlangsung lebih cepat dan secara masif. Hal ini memperlihatkan bahwa pada akhirnya khalayak dijadikan komoditas agar pelaku industri tidak perlu mengeluarkan modal lebih banyak untuk mendapatkan hasil yang maksimal. Realitas ini menggambarkan bahwa, membangun hubungan buzzer dengan pengguna media social menjadi penting, agar dapat memanfaatkan media social secara tepat seperti halnya pemanfaatan E-mail, blog, ataupun Twitter (Muchtar \& Aliyudin, 2019)

Fenomena buzzer politik di media sosial tidak terlepas dari terjadinya komodifikasi terhadap pekerja. Komodifikasi pekerja berhubungan dengan tugas mereka dalam memproduksi dan mendistribusikan produk media yang mungkin saja tidak sesuai dengan upah ataupun beban kerja. Penguasa dalam hal ini memiliki kontrol terhadap pekerja untuk meningkatkan profit finansial. Pekerja dalam hal ini memiliki tugas untuk menjadikan khalayak sebagai komoditas.

Berdasarkan alur kerja yang dilakukan oleh buzzer yang dijelaskan oleh Felicia (2019), buzzer profesional akan mengadakan open recruitment terhadap kalangan mahasiswa yang memiliki pandangan ideologi yang sama terhadap calon pasangan tertentu. Buzzer profesional sengaja memilih kalangan muda karena mereka memiliki keahlian menggunakan teknologi serta memiliki kreativitas yang tinggi dalam menyusun suatu pesan. Meskipun dibalik canggihnya anonimitas, mereka merasa tidak nyaman bekerja karena jeruji besi telah menunggu para mahasiswa jika mereka dilaporkan menggunakan UU ITE. Para mahasiswa dalam hal ini telah terjerumus dalam sisi gelap kampanye politik yang seharusnya bisa menjadi ajang untuk mendewasakan cara berfikir merka 
tentang dunia politik. Jika benar para tokoh elit politik yang menggerakan dan mendanai buzzer maka mereka telah berperan dalam merusak cara berpolitik kaum muda.

\section{PENUTUP}

Buzzer yang pada awalnya dimaknai sebagai suatu aktor yang bertugas untuk mengamplifikasi pesan di media dalam konteks promosi bisnis telah mengalami pergeseran konsep akibat kontestasi politik di dunia. Pergeseran konsep turut dipengaruhi oleh momentum pemilihan presiden di Amerika Serikat yang dalam hal ini dikotori oleh berbagai pesan-pesan provokatif oleh buzzer politik. Di Indonesia sendiri, bu₹zer turut dimaknai sebagai kaki tangan suatu pihak untuk mencapai tujuan politiknya dengan cara menyampaikan pesan-pesan yang provokatif atau bersifat menyerang isu pribadi. Berdasarkan beberapa momentum tersebut, pada akhirnya buzzer sendiri menjadi konsep yang secara umum berada dalam konteks politik dan memiliki stereotip negatif.

Temuan penelitian ini menunjukan bahwa terdapat relasi antara berbagai aktor yang ingin mencapai tujuan politiknya dengan menggunakan buzzer politik. Dalam konteks mempertahankan kekuatannya, Pemerintah diindikasikan telah menggunakan buz:erer politik untuk melakukan perlawanan terhadap serangan konten-konten dari pihak oposisi. Bahkan aktor pengelola buzzer pemerintah tersebut diindikasikan mendapat imbalan dalam bentuk kursi jabatan dalam suatu institusi. Adapun dalam konteks kontestasi politik, berbagai aktor dari pihak oposisi diindikasikan turut menjadi buzzer politik dengan menyampaikan berbagai isu SARA. Pada akhirnya, seluruh aktor yang terlibat dalam fenomena industri buzzer dinilai telah menciptakan suatu hegemoni bahwa cara berpolitik dengan mekanisme saling serang atau memprovokasi adalah cara berpolitik yang benar.

Regulasi merupakan salah satu alat yang digunakan oleh pihak pengeuasa untuk teteap mempertahankan kekuasaannya. UU ITE yang awalnya dirancang untuk memberikan keamanan dan kenyamanan dalam bertransaksi maupun berkomunikasi melalui internet, dalam implementasinya menjadi alat bagi suatu pihak untuk mempertahankan kekuasaannya. Dalam hal ini, UU ITE yang bertugas sebagai landasan hukum bagi ujaran kebencian tidak bekerja pada buzzer-buzzer politik di pihak yang berkuasa. Selain itu, UU ITE tetap digunakan oleh pihak yang berkuasa untuk menjerat pihak-pihak oposisi yang melontarkan ujaran kebencian. Pihak yang berkuasa dinilai secara sengaja membiarkan fenomena ini terjadi sehingga mereka tetap mampu mempertahankan kekuasaannya.

Berdasarkan teori ekonomi politik, buгzer telah melakukan praktik spasialisasi, komodifikasi serta telah melanggengkan strukturasi dalam industri 
Shiddiq Sugiono

buzzer itu sendiri. Pelaku Industri buzzer telah memanfaatkan momentum kontestasi politik di Indonesia untuk mendapatkan profit finansial. Isu mengenai identitas ataupun kehidupan pribadi seseorang telah diubah menjadi suatu komoditas untuk menciptakan pesan-pesan politik yang kurang berkualitas. Buzzer politik telah menggunakan segala lini media sosial untuk melancarkan aksinya sehingga dapat memperluas jangkauan khalayak. Industri buzzer pada akhirnya dinilai sebagai kemunduran dalam menggunakan media komunikasi karena turut menyampaikan pesan-pesan yang dinilai tidak mengindahkan berbagai etika.

\section{DAFTAR PUSTAKA}

Arigi, F. (2019). Pengamat Ungkap Privilese Buzzer Istana, Salah Tak Kena UU ITE.

Ashaf, A. F. (2006). Pola Relasi Media, Negara, Dan Masyarakat: Teori Strukturasi Anthony Giddens Sebagai Alternatif. Sosiobumaniora, 8(2), 205218. https://doi.org/10.24198/SOSIOHUMANIORA.V8I2.5371

Atmaja, A. E. (2014). Kedaulatan Negara Di Ruang Maya: Kritik UU ITE Dalam Pemikiran Satipto Raharjo (State Sovereignty In The Mayan Room: Criticizing UU ITE In Satipto Raharjo Thought). Jurnal Opinio Juris, 16(September), 48-91.

Bradshaw, S., \& Howard, P. N. (2019). The Global Disinformation Order 2019 Global Inventory of Organised Social Media Manipulation.

Conway, B. A., Kenski, K., \& Wang, D. (2015). The Rise of Twitter in the Political Campaign: Searching for Intermedia Agenda-Setting Effects in the Presidential Primary. Journal of Computer-Mediated Communication, 20(4), 363-380. https://doi.org/10.1111/jcc4.12124

Dimedjo, E. (2019). Sejarah Keberadaan Buzzer Politik di Indonesia | Tagar.

Erdianto, K. (2019). Agar Tak Tumpang Tindih, UU ITE dan RKUHP Diminta Sejalan.

Felicia, L. R. (2019). Peran Buzzer Politik dalam Aktivitas Kampanye di Media Sosial Twitter. Koneksi, 2(2), 352. https://doi.org/10.24912/kn.v2i2.3906

Fernandes, A. (2019). Politik Identitas dalam Pemilu 2019: Proyeksi dan Efektivitas. In Centre For Strategic And International Studies.

Gerintya, S. (2018). Betapa Kecilnya Peluang untuk Lepas dari Jerat UU ITE Tirto.ID.

Gerintya, S., \& Garnesia, I. (2019). Jerat Setan "Pasal Karet” - Tirto.ID.

Idris, I. K. (2018). Government social media in Indonesia: Just another information dissemination tool. Jurnal Komunikasi: Malaysian Journal of Communication, 34(4), 337-356. https://doi.org/10.17576/JKMJC-20183404-20

Jati, W. R. (2017). Aktivisme Kelas Menengah Berbasis Media Sosial: Munculnya Relawan dalam Pemilu 2014. Jurnal Ilmu Sosial Dan Ilmu Politik, 20(2), 147. 
https:// doi.org/10.22146/jsp.24795

Lestari, D. (2019). Pilkada DKI Jakarta 2017: Dinamika Politik Identitas di Indonesia. Simulacra: Jumal Sosiologi, 2(1), 31. https://doi.org/10.21107/sml.v2i1.5519

Lipson, D. (2018). Indonesia's "buzzers" paid to spread propaganda as political elite wage war abead of election - ABC News (Australian Broadcasting Corporation).

Manggaga, I. P. (2019). Komodifikasi Konten Televisi Dalam Perspektif Ekonomi Politik Media. Jurnal Dakwah Tabligh, 19(2), 257-276.

Mosco, V. (2009). The Political Economy of Communication: Building a Foundation. In The Political Economy of Communication. https://doi.org/10.4135/9781446279946.n5

Muchtar, K. (2016). Komunikasi Politik dan Pembentukan Citra Partai. Jurnal Ilmu Komunikasi, 14(2), 136-147.

Muchtar, K., \& Aliyudin. (2019). Public Relations Politik Partai Keadilan Sejahtera dalam Pemilukada Jawa Barat. Communicatus: Jurnal Ilmu Komunikasi, 3(1), 61-78. https://doi.org/10.15575/cjik.v3i1.5047

Murwani, E., \& Elmada, M. A. G. (2019). Social media literacy and politic participation early voter in tangerang. Jurnal Sinergitas PKM Dan CSR, 3(2), $23-25$.

Mustika, R. (2019). Pergeseran Peran Buzzer ke Dunia Politik di Media Sosial Shifting The Role of Buzzer To The World of Politics on. 2(2), 144-151.

Noviandari, L. (2015). Statistik. Pengguna Internet dan Media Sosial Terbaru 2015.

Nursatyo, N. (2012). Relasi Agen Dan Struktur Dalam Menata Kepemilikan Media Televisi Swasta Di Indonesia (Kajian Strukturasi Ekonomi Politik atas Dinamuka Interaksi dalam Kasus Akuisis IDKM oleb EMTEK serta Proses Uji Materi UU Penyiaran di Mabkamah Konstitusi Tabun 2011-201. Universitas Indonesia.

pinterpolitik.com. (2019). Dandhy Tersangka, Kalau Denny Siregar?

Prabowo, H. (2019). Beda Perlakuan ke Buzzer 01 dan 02, Polri Dikritik. Aktivis Tirto.ID.

Saraswati, M. S. (2018). Social Media and the Political Campaign Industry in Indonesia. Jurnal Komunikasi Ikatan Sarjana Komunikasi Indonesia, 3(1). https://doi.org/10.25008/jkiski.v3i1.124

Syahputra, I. (2017). Demokrasi Virtual Dan Perang Siber Di Media Sosial: Perspektif Netizen Indonesia. Jurnal ASPIKOM, 3(3), 457. https://doi.org/10.24329/aspikom.v3i3.141

Taylor, G. S. (2016). Pengamat Menilai Buұzer Medsos Jadi Alat Kemenangan Trump.

Triantoro, D. A. (2019). Praktik Politik Identitas dalam Akun Media Sosial Anies-Sandi. Jurnal Ilmu Komunikasi, Vol. 16(1), 19-39.

Yovita, Y. (2017). Kementerian Komunikasi dan Informatika. 
Shiddiq Sugiono 